\title{
Public perception and acceptance of ornamental pineapple hybrids ${ }^{(1)}$
}

\author{
GABRIELLA NAVARRO DONATO PEREIRA(2), EVERTON HILO DE SOUZA ${ }^{(2)}$, JOSÉ DA SILVA SOUZA(3), \\ FERNANDA VIDIGAL DUARTE SOUZA ${ }^{(2,3)^{*}}$
}

\begin{abstract}
Ornamental pineapple varieties are promising alternatives for the cut flower, potted plant and landscaping segments. New hybrids from the genetic improvement program of Embrapa Mandioca e Fruticultura (Embrapa Cassava and Fruits research unit) are being launched for these purposes. The objective of this work was to evaluate the acceptance and preference of consumers regarding the esthetics and prices of potted plants, floral stems and other products originating from ornamental pineapple plants. A survey was conducted at the 15th International Fair of Landscaping, Gardening, Leisure and Floriculture (Fiaflora Expo Garden) in the city of São Paulo. Individual interviews were conducted with 205 people, who answered a questionnaire in a random and voluntary manner, considering the following aspects: gender, age group, origin, profession, flowers of interest, acceptance of cut stems (including in the budding stage), potted plants and mini-fruits and amounts they would pay for these items. The results showed excellent acceptance by the public for cut stems (infructescence or budding stage), potted plants and mini-fruits. Most of the respondents were women, aged between 40 and 50 years, involved in landscaping and from the Southeast region of Brazil. The suggested prices for stems ranged from $\mathrm{R} \$ 3.01$ to $\mathrm{R} \$ 10.00$ and for potted plants the prices were above $\mathrm{R} \$ 20.00$.
\end{abstract}

Keywords: Ananas comosus (L.) Merrill, marketing, ornamental fruit trees, consumers.

\section{RESUMO}

Estudo da percepção pública e aceitação de híbridos de abacaxizeiros ornamentais

O abacaxizeiro ornamental se constitui numa alternativa promissora para o segmento das fruteiras ornamentais. Novos híbridos oriundos do programa de melhoramento genético da Embrapa Mandioca e Fruticultura estão sendo lançados e demandam ações que permitam sua inserção no mercado de flores e plantas ornamentais. Em vista disso, o objetivo desse trabalho foi avaliar a aceitação e a preferência dos consumidores quanto ao preço dos produtos de hastes florais, plantas envasadas e outros oriundos dos abacaxizeiros ornamentais, em uma feira internacional de flores. A pesquisa foi realizada na $15^{\text {a }}$ Feira Internacional de Paisagismo, Jardinagem, Lazer e Floricultura, Fiaflora Expogarden, São Paulo-SP. Os dados foram captados por meio de levantamento de dados primários e entrevistas individuais. Participaram da entrevista 205 pessoas, que responderam a um questionário de maneira aleatória e voluntária onde foram considerados os seguintes aspectos: gênero, faixa etária, estados de origem, profissão, flores de interesse, aceitação da haste cortada, da planta envasada, da haste cortada em fase de botão, dos minifrutos e dos valores pagos pela haste e pela planta envasada. Os resultados obtidos mostraram uma excelente aceitação do público, tanto para haste cortada (infrutescência ou botão) como nas plantas envasadas e minifrutos. A maioria do público era de mulheres, com idade entre 40 e 50 anos, paisagistas e da região sudeste. O valor sugerido para venda das hastes de abacaxizeiros variou de $R \$ 3,01$ a $R \$ 10,00$ e para plantas envasadas acima de R $\$ 20,00$.

Palavras-chave: Ananas comosus (L.) Merrill, comercialização, fruteiras ornamentais, consumidor.

\section{INTRODUCTION}

The use of fruit-bearing plants for ornamental purposes has been increasing in recent years, making the development of such varieties an interesting alternative for the cut flower and ornamental plant segments (SOUZA et al., 2012a; 2012b). Globally, ornamental horticulture generates revenues of more than US\$ 100 billion annually, considering the entire productive chain (IBRAFLOR, 2015). The ornamental horticulture may be considered one of the agricultural activities that most employ, involving about one million people, demanding intensive and qualified labor (SEAGRI, 2015).

The ornamental fruit crops has been emerged as an interesting alternative with differentiated and original products for use as cut flowers, potted plants, foliage and mini fruits (SOUZA et al., 2012c; 2014; SANTOS et al., 2015; COLOMBO et al., 2017; NÓBREGA et al., 2017).

In Brazil, despite recent growth in this market segment, demand for cut flowers and ornamental plants is very uneven (MARQUES and CASTRO FILHO, 2003). In particular,

http://dx.doi.org/10.14295/oh.v24i2.1154

(1) Received in 15/02/2018 and accepted in 28/05/2018

(2) Universidade Federal do Recôncavo da Bahia (UFRB), Cruz das Almas-BA, Brazil.

(3) Embrapa Mandioca e Fruticultura, Cruz das Almas-BA, Brazil. *Corresponding author: fernanda.souza@embrapa.br.comLicensed by CC BY 4.0 Licensed by CC BY 4.0 
the consumption of cut flowers by Brazilians is still small, mainly due to the lack of habit of giving flowers and the high cost (MIELKE et al., 2008). Domestic consumption is concentrated in the decoration, floriculture and landscaping segments. In the case of cut flowers, consumption mainly occurs on commemorative days (Mother's Day, Valentine's Day and Day of the Dead) (JUNQUEIRA and PEETZ, 2008).

In the ornamental plants market, two sales lines can be exploited: floriculture (with high added value) and mass consumption, at garden centers, supermarkets and over the Internet (with modest aggregate value) (SEBRAE, 2015a).

Before launching innovative products in the market, it is important to conduct opinion surveys to discover the knowledge of the population and the potential acceptance by consumers (LANE and SEARS, 1996).

These studies can also provide insights for the development of other products (such as those from genetic improvement). The success of a product in the market obviously depends on many factors, such as quality, new selling tools and advertising and marketing strategies, including customer loyalty programs (DETTMER et al., 2002).

The production of cut flowers and ornamental plants has been growing considerably in Brazil and the rest of the world, gaining greater economic importance. Brazil has around 8,000 producers of cut flowers and ornamental plants, from a cultivated area of 13,800 thousand hectares, involving more than 350 species and around 3,000 cultivars of plants for pots, flowers and gardens, in the last case including bushes and trees (IBRAFLOR, 2015). Nevertheless, Brazil has low ranking in international trade of these products. Of the 171 countries analyzed in a study conducted in 2013, it occupied 42nd position in exports (with $0.11 \%$ of the market) and 41 st in imports $(0.22 \%)$, well behind Holland, Colombia, Germany, Belgium and Italy, among others (SEBRAE, 2015b).

The floriculture productive chain has been growing modestly but steadily, providing employment and income for farmers throughout the country. From 2008 to 2013, the number of people engaged in this activity, the area cultivated and the gross revenue from production grew, despite the global crisis, permitting good profitability of the sector (JUNQUEIRA and PEETZ, 2014).

In more recent years, the sector has been growing substantially, with revenues reaching $\mathrm{R} \$ 5.7$ billion in 2014, $\mathrm{R} \$ 6.2$ billion in 2015 and $\mathrm{R} \$ 6.6$ billion in 2016 (6\% higher than the previous year), generating almost 216 thousand direct jobs in the steps of production $(36.37 \%)$, distribution (3.9\%) and retailing (55.87\%) (IBRAFLOR, 2015). Among the species produced in Brazil for ornamental purposes, $80 \%$ are tropical plants, providing margin for expansion in the foreign market (SEBRAE, 2015b). This preponderance of tropical species is explained by the country's edaphoclimatic conditions, allowing these plants to be grown virtually year round in most regions of the country. Pineapple stands out in this scenario for being native to Brazil and presenting wide variability and good versatility of forms of use (Figure 1) (SOUZA et al., 2012a; 2014).

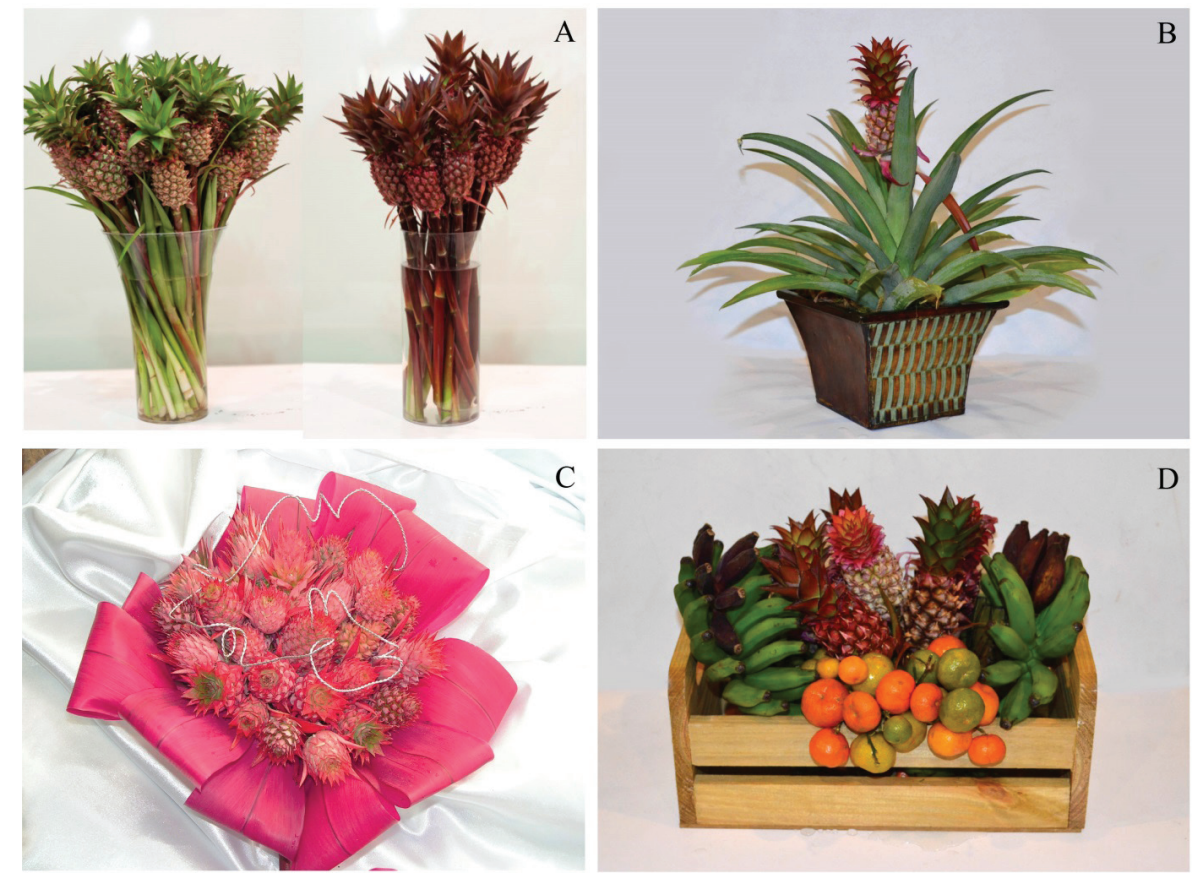

Figure 1. Example of different uses of ornamental pineapple plants. A) stems in a pot; B) potted plants; C) use of floral buds in bouquets; D) ornamental mini-fruits composing a fruit bowl. 
There are no official data on the production and sale of ornamental pineapple plants and flowers in Brazil and the world. The main producing region in Brazil is the Northeast, with the standouts being the states of Ceará and Rio Grande do Norte, which together account for $75 \%$ of regional output, mainly for the foreign market for cut flowers (BRAINER and OLIVEIRA, 2007). The production of ornamental pineapple plants is concentrated in only three botanical varieties, $A$. comosus var. erectifolius (responsible for $75 \%$ of sales revenue), $A$. comosus var. bracteatus and $A$. comosus var. microstachys (BRAINER and OLIVEIRA, 2007). In 2016, Embrapa Cassava and Fruits launched two new cultivars, BRS Anauê and BRS Boyrá, which are now being cultivated and will be exported in the near future, mainly to European countries (EMBRAPA, 2016a; 2016b).

According to Junqueira and Peetz, (2011), ornamental pineapple products are the main Brazilian tropical species in penetration of the European market, followed by heliconia, among other tropical plants for flowers and foliage. In contrast, the reasons for the relatively lesser penetration of ornamental pineapple products in the domestic market are unknown; hence, the need for studies among prospective consumers to discover their needs and preferences, to fill in the information gaps about this culture.
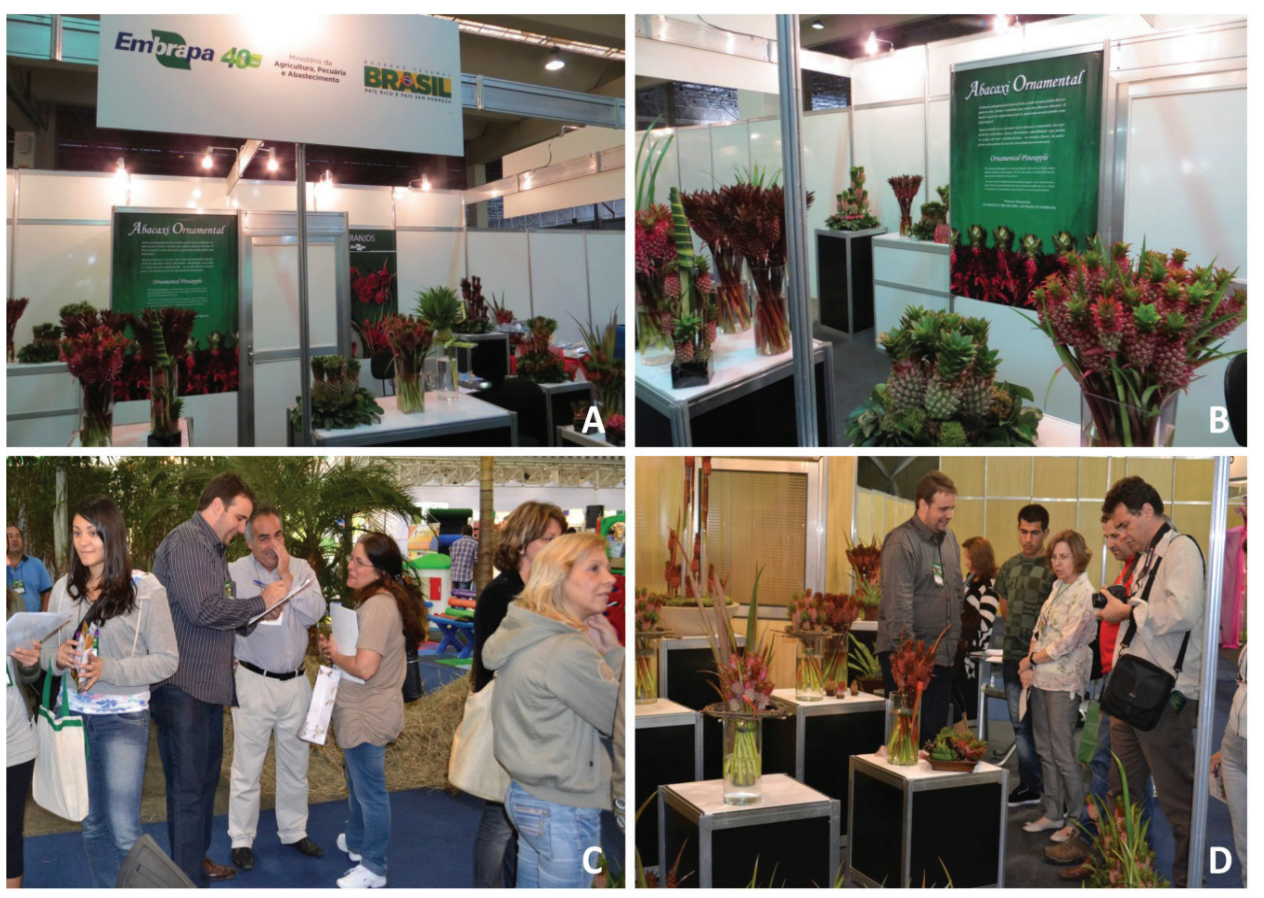

Figure 2. The 15th International Fair of Landscaping, Gardening, Leisure and Floriculture (Fiaflora Expogarden), held from October 6-9, 2011, in the West Pavilion of the Anhembi Exposition Center in São Paulo, Brazil. Organization of the stand and presentation of the products (A-B); Application of the questionnaires (C-D).

This annual event is the main one in the floriculture sector in Latin America. This version of the event attracted about 30,000 visitors, made up of landscape architects, decorators, distributors, shopkeepers, buyers of garden centers and home centers, commercial representatives, agronomists, gardeners and consumers. The survey
One of the main ways to obtain information about the acceptance of a product that will be offered to the consumer market is to conduct opinion surveys (GERHARDT and SILVEIRA, 2009). These are fundamental to obtain information on which to base decisions in the future, especially to guide efforts of genetic improvement programs (LANE and SEARS, 1966). Various tools can be used to gain knowledge of popular opinion about a determined subject. The two leading techniques are interviews, either one-on-one or in focus groups, and questionnaires, administered either in person or over the internet (SANTOS et al., 2013).

The objective of this study was to evaluate the acceptance and preference of consumers regarding the esthetic aspects and pricing of floral stems (infructescences and buds), potted plants and ornamental varieties of pineapple producing minifruits at an international flower and gardening fair.

\section{MATERIAL AND METHODS}

The opinion survey was conducted at the 15th International Fair of Landscaping, Gardening, Leisure and Floriculture (Fiaflora Expogarden), held from October 6 to 9, 2011 in the West Pavilion of the Anhembi Exposition Center in São Paulo, Brazil (Figure 2). aimed to elicit the opinions by application of a structured questionnaire (FREITAS et al., 2000).

The stand was organized to focus attention on floral arrangements of cut stems bearing flowers and potted plants (Figure 2 A-B), to elicit opinions of visitors. Among the hybrids used were BRS Anauê and BRS Boyrá, still in the 
evaluation phase. Descriptive and qualitative information was obtained by random application of 205 questionnaires to participants at the event (Figure $2 \mathrm{C}$-D). The overall aims were to measure the acceptance of cut stems and potted plants of the different pineapple hybrids and the price elasticity of consumers.

In the questionnaires, we considered market aspects (consumption of flowers, acceptance of floral stems, acceptance of potted plants, acceptance of floral buds and acceptance of mini fruits), demographic aspects (profession, home state, age range and gender) and economic aspects (amount respondents would be willing to pay for floral stems and potted plants, in Brazilian currency (Real - R\$).

All told, we displayed five pineapple hybrids with ornamental potential for commercial launch, resulting from the Genetic Improvement Program of Embrapa Cassava and Fruits, including BRS Anauê. These hybrids were developed particularly for the cut flower segment, and had distinct traits of color, fruit size, crown/fruit ratio, presence or absence of spines and sinuosity of the stem, among others.

The data from the 205 respondents were treated with Microsoft Excel $2010^{\circledR}$, to produce spreadsheets and graphs.

\section{RESULTS AND DISCUSSION}

The demographic data on the sample from the 15th International Fair of Landscaping, Gardening, Leisure and Floriculture revealed that the majority $(65 \%)$ were women (Figure 3A), residing in the Southeast region $(77 \%)$, mainly from the state of São Paulo (71.7\%), followed by Rio de Janeiro (5.3\%), while the South region was represented mainly by the state of Paraná (3.9\%). All told, the respondents came from 19 Brazilian states (Figure 3B).
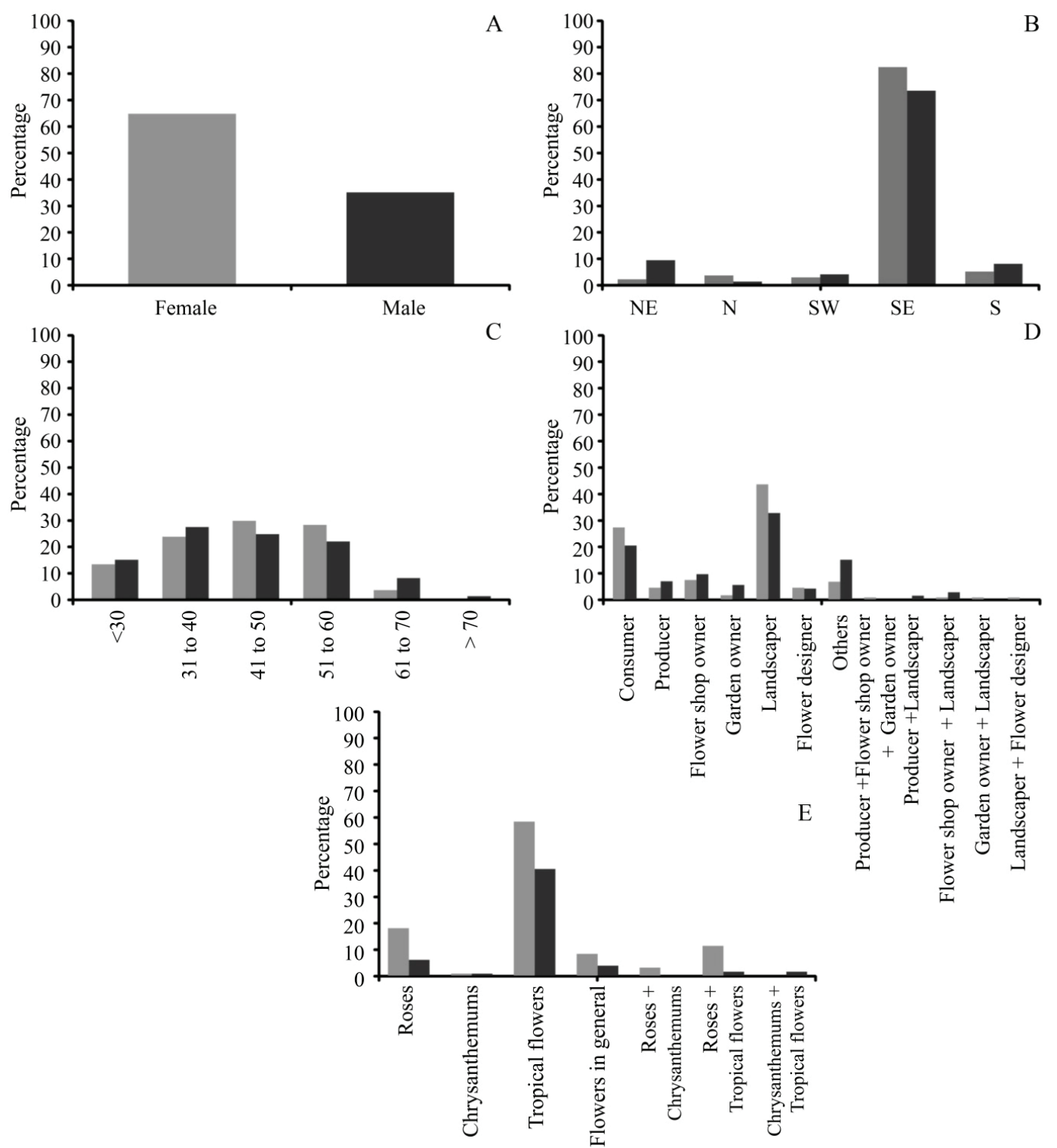

Figure 3. Profile of the respondents at the 15th International Fair of Landscaping, Gardening, Leisure and Floriculture (Fiaflora Expogarden). A) gender; B) origin; C) age range; D) profession/activity; E) types of flowers consumed most. Bars: gray (female); black (male). 
The predominance of residents of the state of São Paulo was due not only to the fact the event was held in the capital city, but also because the state accounts for $56 \%$ by value of ornamental plant products in the country, from a cultivated area of 6,850 hectares, distributed in most parts of the state, representing $45 \%$ of the national area (IBRAFLOR, 2015).

Besides being the main producer, the state is also the main exporter of floriculture products, and the home of the largest centers for distribution of flowers and ornamental plants ( $90 \%$ on a national basis), among them Companhia de Entrepostos e Armazéns Gerais de São Paulo (CEAGESP), Central de Abastecimento S.A. (CEASA), in the city of Campinas, Veiling Holambra (where the largest producers are concentrated, using the latest technology for flower production), Cooperflora and Cooperativa SP Flores, among others (BATALHA and BUAINAIN, 2007). The Brazilian population spends a yearly per capita average of $\mathrm{R} \$ 26.27$ on ornamental plant products, of which $41.55 \%$ is spent on plants for landscaping and gardens, 34.33\% for cut flowers and foliage, and $24.12 \%$ for potted plants (SEBRAE, 2015b).

The highest per capita consumption is in the Federal District (R\$ 44.23), followed by the states of Minas Gerais (R\$ 43.40), Rio de Janeiro ( $\mathrm{R} \$ 41.53$ ), Santa Catarina (R\$ 37.84), São Paulo (R\$ 35.52) and Rio Grande do Sul (R\$ 35.34) (SEBRAE, 2015b).

In our sample, the age range of the respondents varied from 21 to over 70 years. Although the largest concentration was in the age range of 41 to 50 years $(28 \%)$, there was substantial presence in the ranges of 31 to $40(25.26 \%)$ and 51 to $60(26.34 \%)$. Only $1.0 \%$ of the respondents were older than 70 years (Figure 3C). In a study to learn the profile of consumers of flowers and plants in the city of Santa Maria, Rio Grande do Sul state, Santos et al. (2013) observed predominance in the range of 41 to 50 years old, and the majority of consumers were women.

With respect to profession, $40 \%$ were involved with landscaping, $25 \%$ were common consumers, $8 \%$ owners of floriculture companies, $5 \%$ were flower producers, $3 \%$ were flower shop owners and $19 \%$ fell in other categories, such as floral designer and decorator (Figure 3D). All told, $75 \%$ of the respondents were drawn from the floriculture and landscaping segments, a fact explained by the nature of the event, making the results of this study even more important and consistent.

Lara and Carvalho (2003), in a study of the profile of consumers of ornamental plants and flowers in the city of Curitiba, in the Southern state of Paraná, conducted random interviews with people of different ages, education and socioeconomic levels. These people were interviewed in high schools, universities and residences, to obtain information about the frequency of purchase and the floriculture preferences, as well as aspects of the establishments that sell the products. In this last aspect, the authors found that flower shops in the city of Curitiba are typically opened without previous market studies, and the owners invest very little in marketing. They also found that consumption of flowers is sporadic, given as presents on commemorative occasions.

In our sample, among the types of flowers consumed, tropical flowers stood out (64\%), followed by roses $(15.6 \%)$ (Figure 3E). This result is directly related to the profile of the respondents, because $40 \%$ were involved in the landscaping field. The cultivation of tropical ornamental plants can be a highly profitable alternative for farmers, because the area needed is not extensive and a wide diversity of tropical plants can be grown with uncomplicated labor by family members (TERRA and ZÜGE, 2013).

When asked about the purchase of ornamental pineapple stems, $97 \%$ of the respondents stated they would purchase them, while only $2.43 \%$ expressed doubt about buying them (Figure 4A; 5A). The material presented (stems and potted plants) was assessed regarding acceptance of consumers, with scores from 0 to 10. For stems, the score of 10 was attributed by $87.8 \%$ of the respondents, followed by a score of $8(6.34 \%)$, clearly revealing the good acceptance of the product (Figure 4B). 

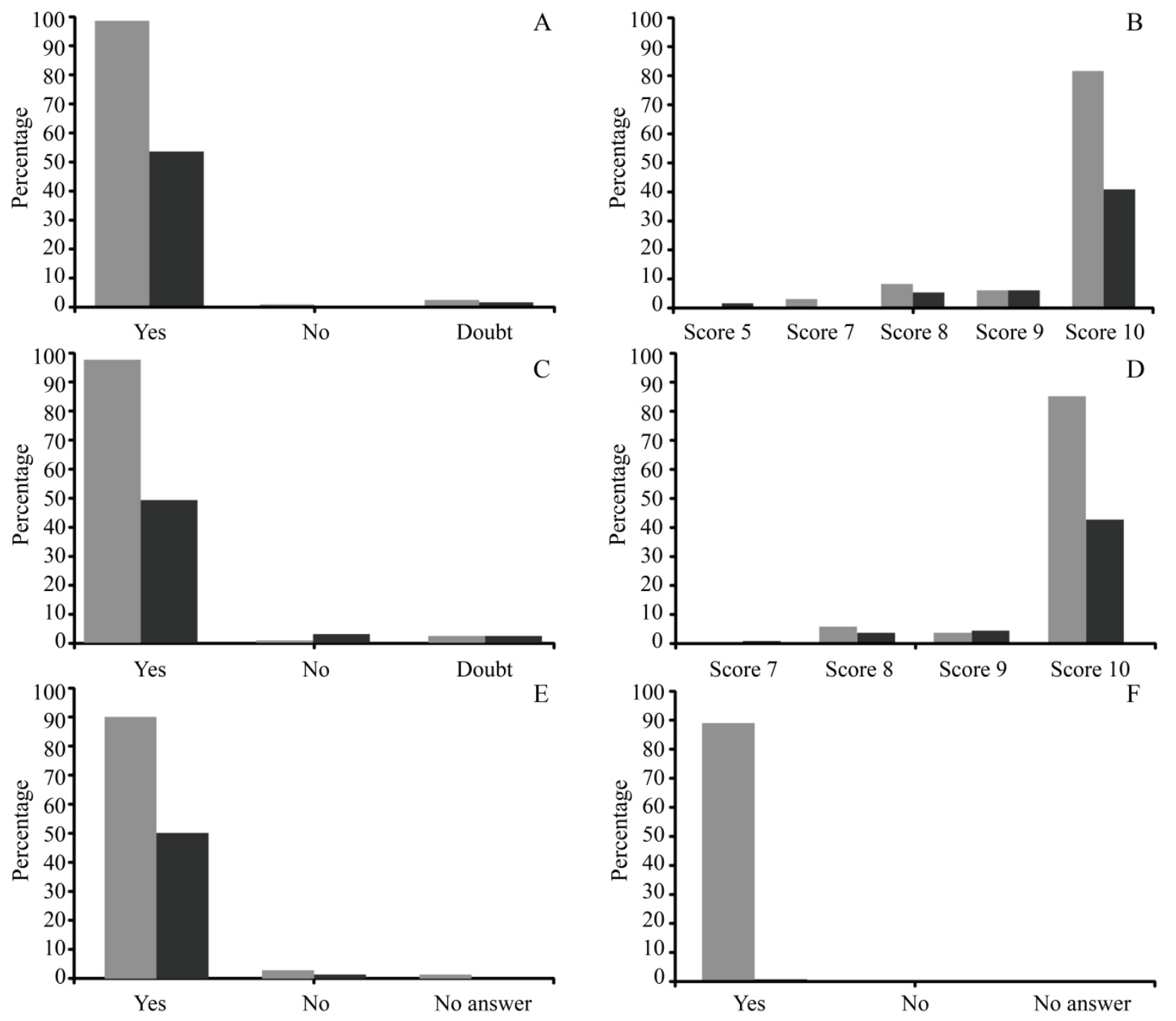

Figure 4. Exploratory survey conducted at the 15th International Fair of Landscaping, Gardening, Leisure and Floriculture (Fiaflora Expogarden) regarding acceptance of ornamental pineapple stems (A-B); potted plants (C-D); buds (E) and ornamental mini-fruits (F). Bars: gray (female); black (male).

In relation to potted pineapple plants, $94.63 \%$ of the respondents said they would purchase the product (Figure 4C), while only $2.44 \%$ said they would definitely not buy it. The score of 10 was attributed by $80.5 \%$ of the sample, followed by $8(8.78 \%)$ (Figure 4D). Potted plants take up little space, are of course more durable than stems and their care is normally simple. The size and shape of the pot should also be considered to assure good development of the plant.

With respect to stems in the budding phase, 92.0\% stated they would buy this product while 5.8\% did not express interest (Figure 4E). Pineapple buds should be collected before opening of the flowers, and configure a very interesting and differentiated product, since the buds preserve the beauty and exuberance of colors without the presence of the crown. Despite not having the appearance of the fruit, they can be used in garlands and bouquets to lend a tropical touch. Some experiments for this purpose have showed very interesting results.
Furthermore, $95 \%$ of the respondents indicated interest in buying ornamental plants bearing mini-fruits (Figure $4 \mathrm{~F}$ ), considered attractive for having different colors and sizes. Their use in floral arrangements is a novelty in the ornamental plant market (SOUZA et al., 2012a), with potential to surpass consumers' expectations. In the sample presented, the miniature pineapple fruits were displayed together with banana and citrus mini-fruits, composing a fruit bowl that attracted strong attention from the public. They can also be used in niches, such as bridal showers and weddings etc. According to Junqueira and Peetz (2014) and SEBRAE (2015a), the Brazilian market for flowers and ornamental plants is expanding, causing an ongoing need to develop new products and services.

To evaluate the potential of other hybrids by identifying preferences for attributes that can guide the development of varieties for future launches, plants of five new hybrids selected by Embrapa's genetic improvement program were displayed (Figure 5). 

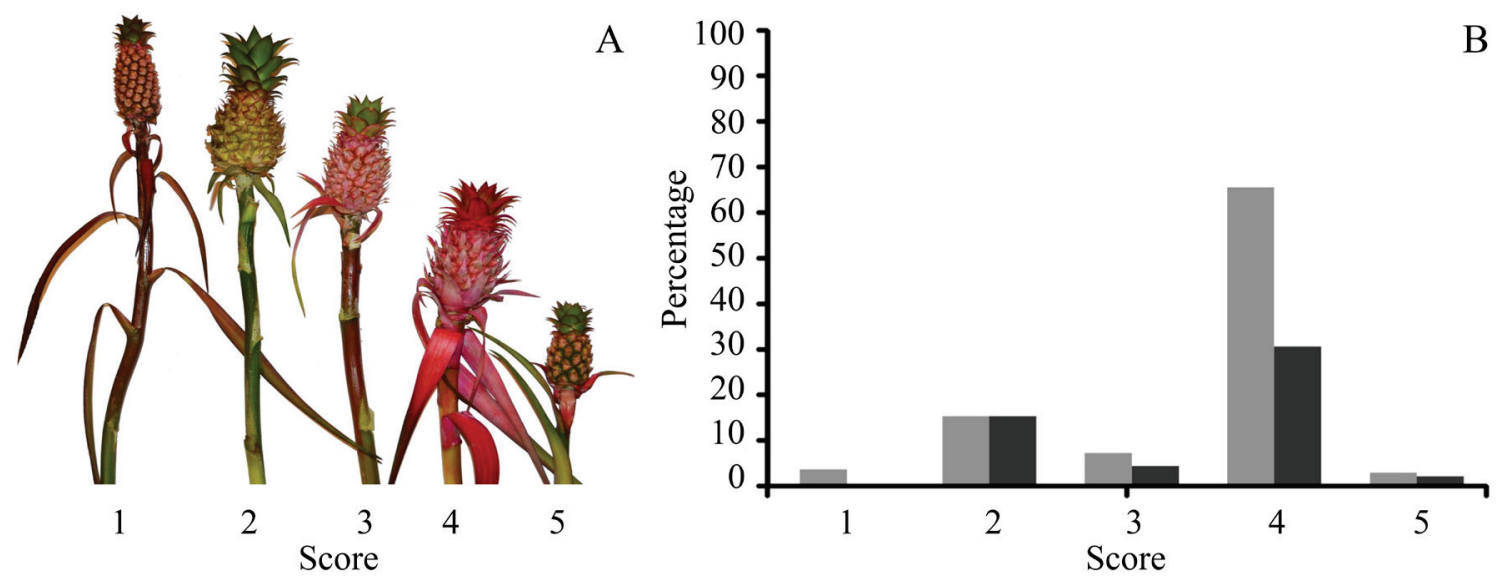

Figure 5. A) Hybrid pineapple plants with ornamental potential presented at the 15 th International Fair of Landscaping, Gardening, Leisure and Floriculture (Fiaflora Expogarden). B) Acceptance scores of ornamental pineapple hybrids developed by the improvement program f Embrapa Cassava and Fruits for possible commercial launch. Bars: gray (female); black (male).

The choice of these hybrids was based on the marked differences among them, regarding stem length, shape, color, crown/fruit ratio etc. Hybrid 4 received the most votes with $64.3 \%$, followed by hybrid 2 (21\%), 3 (8\%), 5 (4\%) and hybrid 1 (2.7\%) (Figure 5). Hybrid 4 has a dark pink syncarp, with fruitlets covered by long pink bracts, a more intensely colored crown and a balanced syncarp/ crown ratio (near 1) according to the standards established by Souza et al. (2014). The stem is approximately $40 \mathrm{~cm}$ long, considered ideal for sale, mainly in the international market (SOUZA et al., 2014).

Hybrid 3 was 'BRS Anauê', launched in 2016, with a production system already well established. On the other hand, hybrid 4, although having passed through all the clonal evaluations and culture validation, still needs adjustments in the commercial cultivation system, so its launch has been delayed, despite its popularity among the public (Figure 5).

Finally, regarding the economic aspects covered in the questionnaire, specifically the price respondents would be willing to pay for an ornamental pineapple stem, the range was from $\mathrm{R} \$ 3.00$ to $\mathrm{R} \$ 10.00$. The intermediate category (from R\$ 3.01 to $\mathrm{R} \$ 5.00$ ) corresponded to $29.7 \%$ of the responses, followed by $\mathrm{R} \$ 5.01$ to $\mathrm{R} \$ 8.00$ with $21.5 \%$ and $\mathrm{R} \$ 8.01$ to $\mathrm{R} \$ 10.00$ with $21.5 \%$ (Figure 6A). For potted plants, the variation was from R\$ 5.00 to above $\mathrm{R} \$ 20.00$. The top value range of more than $\mathrm{R} \$ 20.00$ corresponded to $35.12 \%$, followed by the intermediate range of $\mathrm{R} \$ 15.01$ to $\mathrm{R} \$ 20.00$, with $27.8 \%$, and the interval from $\mathrm{R} \$ 10.01$ to $\mathrm{R} \$ 15.00$ with $16.6 \%$ (Figure $6 \mathrm{~B}$ ). This acceptance of higher prices for this product indicates that consumers have a notion of the market price of potted plants.
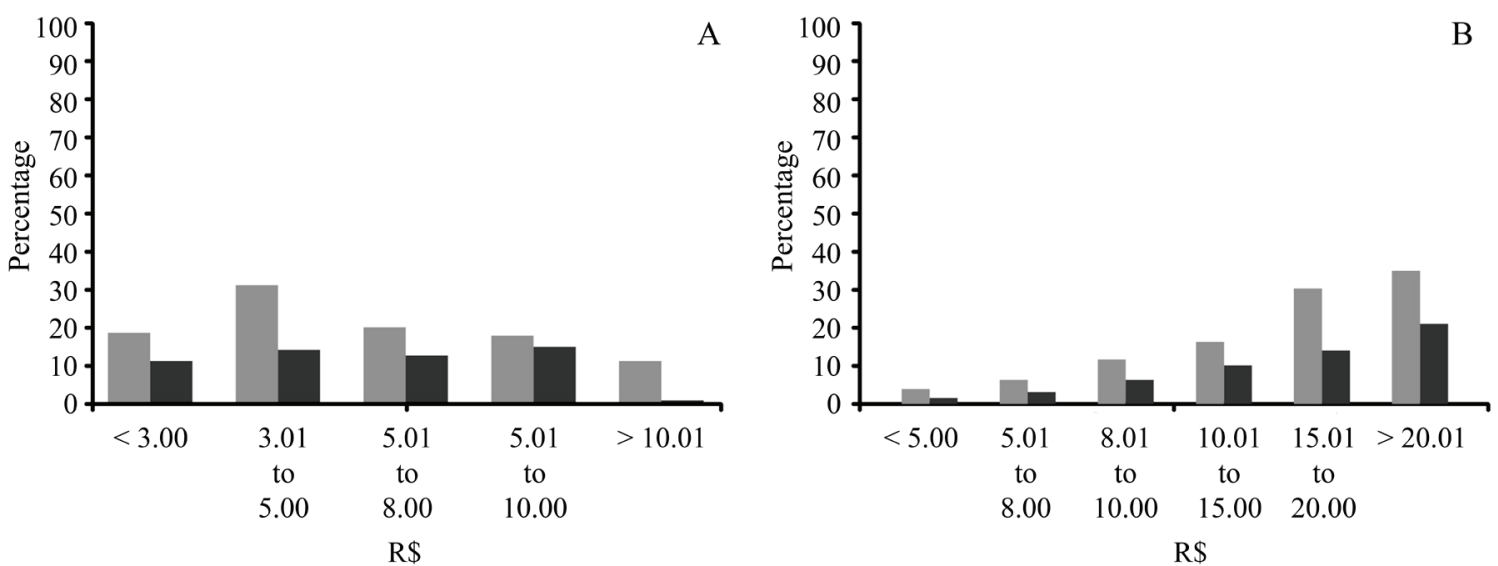

Figure 6. Value (in intervals) to be paid for cut stems (A) and ornamental potted plants (B) at the 15th International Fair of Landscaping, Gardening, Leisure and Floriculture (Fiaflora Expogarden). 
Ornamental pineapple as a potted plant is still a novelty, and can be grown in varied environments, such as houses, apartments, balconies and interior gardens, as well as being easily transported to other places (SOUZA et al., 2012a; 2014). Potted ornamental fruit-bearing plants can be attractive options for people who do not have enough space for gardens, for example. Besides taking up less space, potted plants typically live longer than those grown in gardens, and are easy to care for. The size and shape of the pot should also be considered to assure good development of the plant. Another interesting aspect of potted plants is their use in restricted public spaces, like shopping malls. The decoration of these spaces with plants requires practicality and ease of maintenance. Normally this service is performed by an outsourced company and implies replacement of old plants with new ones, which is easier than maintaining/exchanging plants in a garden.

Prices of R\$ 5.00 and R\$ 20.00 for cut stems and potted plants were considered satisfactory and should be evaluated considering the production costs. The results obtained indicate the existence excellent acceptance levels for the products and willingness to pay the prices suggested.

According to Dutra et al. (2014), the majority of people tend to have traditional attitudes, making them hesitant to accept novelties in the ornamental plant market. This situation prompts the question of what can be done to change this situation.

Ornamental pineapple plants are novel in various aspects. The first aspect is the novelty of fruit-bearing plants for ornamental purposes, and the second is the possibility of presentation both in the form flowers from cut stems and potted form. The general attitude of the public at the event was surprise that a plant producing a widely popular fruit can also be used for ornamental purposes. The miniaturization for this use, although known for other purposes, was a novelty and most respondents were enchanted by the plants on display. On the other hand, ornamental pineapple producers report great difficulty of selling the product in the domestic market, in contrast with the international market. Therefore, it is necessary to understand where efforts need to be focused to overcome the problem of penetration in the Brazilian market of products that have so many positive features and make a good impression on prospective consumers.

\section{CONCLUSIONS}

The products both cut stems (infructescence or bud) and potted plants, received strong acceptance among the respondents. The majority of them were women, with age between 40 and 50 years, involved in landscaping and from the Southeast region. The price suggested for sale of cut stems varied from R \$ 3.01 to R \$ 10.00 and for potted plants values greater than $R \$ 20.00$. The results as a set indicated that all the products were well accepted, independently of the respondent's profile.

\section{ACKNOWLEDGMENTS}

The authors acknowledge the support of Conselho Nacional de Desenvolvimento Científico e Tecnológico CNPq, and Coordenação de Aperfeiçoamento de Pessoal de Nível Superior (Edital CAPES-EMBRAPA 15/2014 and PROCAD 2013) for the scholarships granted.

\section{AUTHORS CONTRIBUTIONS}

G.N.D.P.: data collection and analysis, manuscript preparation and review. E.H.S.: conception and design of the research, data collection and analysis, data analysis and interpretation, manuscript critical review, approval of the final version of the manuscript. J.S.S.: conception and design of the research, obtaining data, analyze and interpretation of data, statistical analysis. F.V.D.S.: conception and design of the research, analyze and interpretation of data, write and critically analyses of manuscript and financial and obtaining funding.

\section{REFERENCES}

BATALHA, M.O.; BUAINAIN, A.M. Cadeias produtivas de flores e mel. Brasília: IICA: MAPA/SPA, 2007. 140p.

BRAINER, M.S.C.P.; OLIVEIRA, A.A.P. Floricultura: perfil da atividade no nordeste brasileiro. Fortaleza: Série Documentos do ETENE n.17, 2007. 354p.

COLOMBO, R.C.; FAVETTA, V.; CRUZ, M.A.; CARVALHO, D.U.; ROBERTO, S.R.; FARIA, R.T. Acclimatization and growth of ornamental pineapple seedlings under organic substrates. Ornamental Horticulture, v.23, n.3, p.257-262, 2017. DOI: https://oi. org/10.14295/oh.v23i3.1040

DETTMER, B.; SOCORRO, C.; KATON, H.T. Marketing de serviços - análise da percepção da qualidade de serviços através da ferramenta Servqual em uma instituição de ensino superior de Santa Catarina. Revista de Ciências da Administração, v.4, n.08, 2002.

DUTRA, A.C.; SOUZA, L.C.; GARCIA, M.H. Marketing de Novos Produtos: Lançamento e Inovação. Caderno Profissional de Marketing-UNIMEP, v.2, n.2, p.53-64, 2014.

EMBRAPA - BRS Anauê: cultivar de abacaxizeiro ornamental para flor de corte e paisagismo. Cruz das Almas: Embrapa Mandioca e Fruticultura, 2016a. 6p. 
EMBRAPA - BRS Boyrá: cultivar de abacaxizeiro ornamental para flor de corte e paisagismo. Cruz das Almas: Embrapa Mandioca e Fruticultura, 2016b. 6p.

FREITAS, H.; OLIVEIRA, M., SACCOL, A.Z.; MOSCAROLA, J. O método de pesquisa Survey. Revista de Administração da USP, v.35, n.3, p.105-112, 2000.

GERHARDT, T.E.; SILVEIRA, D.T. Métodos de pesquisa. Porto Alegre: Editora da UFRGS, 2009. Available in: $\quad<$ http://www.ufrgs.br/cursopgdr/downloadsSerie/ derad005.pdf>. Access on: Feb 1 ${ }^{\text {st }}, 2018$.

IBRAFLOR- INSTITUTO BRASILEIRO DE FLORICULTURA. O mercado de flores no Brasil. 2015. Available in: <http://www.ibraflor.com/publicacoes/ vw.php?cod=235>. Access on: Feb 1 ${ }^{\text {st }}, 2018$.

JUNQUEIRA, A.H.; PEETZ, M.S. Consumo de flores e plantas ornamentais no Brasil. Jornal Entre-posto, p.8, outubro de 2011.

JUNQUEIRA, A.H.; PEETZ, M.S. Mercado interno para os produtos da floricultura brasileira: características, tendências e importância socioeconômica recente. Revista Brasileira de Horticultura Ornamental, v.14, n.1, p.37-52, 2008. DOI: https://doi.org/10.14295/rbho. v14i1.230

JUNQUEIRA, A.H.; PEETZ, M.S. O setor produtivo de flores e plantas ornamentais no Brasil, no período de 2008 a 2013: atualizações, balanços e perspectivas. Revista Brasileira de Horticultura Ornamental, v.20, n.2, p.115-120, 2014. DOI: https://doi.org/10.14295/rbho. v20i2.727

LANE, R.E.; SEARS, D.O. A opinião pública. Rio de Janeiro: Zahar, 1966. 120p.

LARA,A.P.C.; CARVALHO, R.I.N. Perfil dos comerciantes e consumidores de plantas ornamentais em CuritibaPR. Revista Acadêmica: ciências agrárias e ambientais, v.1, n.3, p.55-58, 2003.

MIELKE, E.C.; CUQUEL, F.L.; KOEHLER, H.S.; GEISS, J. Indução de florescimento de plantas de ciclâmen após a aplicação de GA3. Ciência e Agrotecnologia, v.32, n.1, p.87-92, 2008. DOI: http://dx.doi.org/10.1590/S141370542008000100013

NÓBREGA, D.S.; PEIXOTO, J.R.; VILELA, M.S.; FALEIRO, F.G.; GOMES, K.P.S.; SOUSA, R.M.D.; NOGUEIRA, I. Agronomic descriptors and ornamental potential of passion fruit species. Ornamental Horticulture, v.23, n.3, p.357-362, 2017. DOI: https://doi. org/10.14295/oh.v23i3.1053
SANTOS, A.R.A.; SOUZA, E.H.; SOUZA, F.V.D.; FADINI, M.; GIRARDI, E.A.; SOARES FILHO, W.S. Genetic variation of Citrus and related genera with ornamental potential. Euphytica, v.205, n.2, p.503-520, 2015. DOI: https://doi.org/10.1007/s10681-015-1423-2

SANTOS, N.Z.; KIRCHNER, R.M.; SAIDELLES, A.P.F.; LHAMBY, A. Perfil dos consumidores de produtos ornamentais no município de Santa Maria/RS. Revista Eletrônica em Gestão, Educação e Tecnologia Ambiental, v.13, n.13, p.2644-2651, 2013.

SEAGRI - Secretaria da Agricultura, Pecuária, Irrigação, Pesca e Aquicultura. Available in: $<$ http:// www.seagri.ba.gov.br/noticias/2014/09/22/ exporta $\% \mathrm{C} 3 \% \mathrm{~A} 7 \% \mathrm{C} 3 \% \mathrm{~A} 30$-defumo-mant $\% \mathrm{C} 3 \% \mathrm{AAm}-$ cultivo-local>. Access on: Nov 1 $1^{\text {st }}, 2017$.

SEBRAE. Flores e plantas ornamentais: série estudos mercadológicos. vol.1. Brasília: SEBRAE. 2015a. 44p.

SEBRAE. Flores e plantas ornamentais: série estudos mercadológicos. vol.2. Brasília: SEBRAE. 2015b. 100 p.

SOUZA, E.H.; COSTA, M.A.P.C., SOUZA, F.V.D.; COSTA JUNIOR, D.S.; AMORIM, E.P., SILVA, S.O.; SANTOS-SEREJO, J.A. Genetic variability of banana with ornamental potential. Euphytica, v.184, n.3, p.355-367, 2012c. Doi: 10.1007/s10681-011-0553-4

SOUZA, E.H.; COSTA, M.A.P.C.; COSTA JÚNIOR, D.S.; SANTOS-SEREJO, J.A.; SOUZA, F.V.D. Selection and use recommendation in hybrids of ornamental pineapple. Revista Ciências Agronômicas, v.45, n.2, p.409-416, 2014. DOI: http://dx.doi.org/10.1590/S180666902014000200024

SOUZA, E.H.; SOUZA, F.D.; COSTA, M.A.P.C.; COSTA JÚNIOR, D.S.; SANTOS-SEREJO, J.A.; AMORIM, E.P.; LEDO, C.A.S. Genetic variation of the Ananas genus with ornamental potential. Genetic Resources and Crop Evolution, v.59, n.7, p.1357-1376, 2012a. DOI: https://doi. org/10.1007/s10722-011-9763-9

SOUZA, F.V.D.; CARVALHO, A.C.P.P.; SOUZA, E.H. Abacaxi Ornamental. In: PAIVA, P.D.O.; ALMEIDA, E.F.A. (Org.). Produção de Flores de Corte. v.1. Lavras: UFLA, 2012b. p.19-39.

TERRA, S.B.; ZÜGE, D.P. P. O. Floricultura: a produção de flores como uma nova alternativa de emprego e renda para a comunidade de Bagé-Rs. Ponta Grossa, vol. 9, n.2, Jul./Dez. 2013. Available in: <http://www.revistas2.uepg. br/index.php/conexao>. Access on: Nov 1 1, 2017. 